INTERNATIONAL DESIGN CONFERENCE - DESIGN 2018

https://doi.org/10.21278/idc.2018.0202

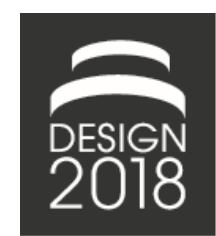

\title{
EXPLORING THE SYNERGISTIC RELATIONSHIPS OF CIRCULAR BUSINESS MODEL DEVELOPMENT AND PRODUCT DESIGN
}

\author{
M. Pieroni, D. Pigosso and T. McAloone
}

\begin{abstract}
Circular economy is a key approach for promoting a sustainable society. The design of innovative circular business models is critical and potentially leads to changes in strategies during product design and development. Systemic approaches relating business models and product design should be reflected in the methodological support for circular transformation. This article investigates this synergistic relationship and, by means of literature review, discusses how circular business modelling approaches address the integration with product design. Gaps and future improvements are outlined.
\end{abstract}

Keywords: circular economy, business models, product design

\section{Introduction}

Increasing recognition of the need to respect planetary boundaries and mitigate future economic risks have led international organizations and scholars to call for a change in the current economic system based on value creation by "taking-making-using-disposing" (Steffen and Stafford Smith, 2013; European Comission, 2014; Häyhä et al., 2016). Circular economy is one of the key approaches to support the transition to a sustainable society. The ultimate purpose of a circular economy is to promote a more resource efficient and "regenerative" industrial system, by slowing, narrowing or closing the loop of material and energy flows (Ellen MacArthur Foundation, 2012; Ghisellini et al., 2016; Lieder and Rashid, 2016; Geissdoerfer et al., 2017). To do that, circular economy initiatives stimulate the establishment of multiple value creation mechanisms (e.g., with enhanced remanufacturing, reuse, recycling) that enable decoupling enhanced business success and revenue growth from the consumption of virgin finite resources (Ellen MacArthur Foundation, 2015).

Although the foundations of a circular economy (such as biomimicry, cradle-to-cradle, industrial ecology, performance economy, and others) exist for decades, implementing such ideas in a synergistic and systemic way (able to reach industrial systems, markets and consumption patterns) is still a challenge (Blomsma and Brennan, 2017). From a business perspective, a circular economy affects several stakeholders in the value chain and requires fundamental changes in multiple business processes and organizational capabilities including product design and development, procurement, manufacturing and operations, direct and reverse logistics, information and communication technology (ICT), business models and so on (Laubscher and Marinelli, 2014; Lieder and Rashid, 2016).

Developing innovative circular business models is critical and one of the topics extensively explored in the field (Lieder and Rashid, 2016; Pigosso and McAloone, 2017). A circular business model is the logic of how an organization creates, delivers and captures value within a vision of boosting resource efficiency and ultimately closing energy and resources flows (Mentink, 2014; Den Hollander and Bakker, 2016). The Danish maternity and baby clothing company Vigga is an example of circular 
business model. By offering access to clothes through a rental/subscription system, Vigga contributes to a reduction of up to eighty percent of resources consumption by enabling reuse of the otherwise shortlived items of clothing by several customers (Vigga, 2017). Another example of circular business model is the long-term service agreement Total Care ${ }^{\circledR}$ commercialized by Rolls-Royce in the aerospace sector. In this solution, Rolls-Royce guarantees maximum flying availability for customers by managing the operation of engines through its life cycle while keeping the engines' ownership. Customers are charged in a "power-by-the-hour" scheme, which means that they only pay for the hours in which engines are performing properly. With this model, Rolls-Royce can keep ninety-five percent of the engines for reusing or remanufacturing (Rolls-Royce, 2018). These two previous examples exploit the circularity potential by selling service-agreements and rethinking the linear concept of ownership to enable value propositions decoupled from transferring the property of the physical product to the customers. However, other types of circular business models are also possible. Two examples are the Norwegian company Norsk Ombruk, which provides a professional life-extension (repair, refurbishment and remanufacturing) and re-sale of used household electric goods, and the Kallundborg Eco-Industrial Park, which consists of an industrial symbiosis involving large energy and processing companies such as pharmaceuticals, medical or cleantech (Kiørboe et al., 2015; Mikkola et al., 2016).

The development of circular business models is intrinsically connected to product design activities. To fulfil longer or multiple use cycles, new products shall be intentionally designed to allow extended lifetime, recyclability and re-manufacturability, modularity, enhanced robustness, adaptability, or other characteristics depending on the strategies of circular economy (Bocken et al., 2016; Lieder and Rashid, 2016). For instance, Vigga had to work with suppliers to develop long-lasting organic materials with timeless look that could be used by different customers regardless of fashion trends and washed several times without wearing out (Vigga, 2017).

To enable a circular economy, product design practices should follow circular business modelling definitions (Bocken et al., 2016; Moreno et al., 2016). Furthermore, the business modelling process should envision current product design practices since the beginning to enable the identification of required changes or the design of products with circular functionalities to make the aspired circular business model feasible. It is a challenge for companies to learn how to integrate business model development and product design processes, and this is part of the systemic challenge of circular economy and sustainability (Colby, 2011; Balkenende and Bakker, 2015). Hence, organizations may benefit and learn from appropriate methodological support.

This article explores the synergistic link between business modelling and product design for circular systems. With a literature review (Section 2), this paper analyses methods proposed for circular business model development (Section 3) and discusses how often and how far they are treating the integration and supporting circular product design (Section 4). Finally, research gaps are identified with the objective of improving current methodological support for the systemic implementation of circular solutions in organizations and the concluding remarks are presented (Section 5).

\section{Research methodology}

A comprehensive review of literature was conducted with the purpose of exploring the existing methods to support the development of circular business models, so as to enable a broader understanding of how they consider or integrate with product design. The review protocol was organized in three parts: data collection, data analysis and data reporting (Biolchini et al., 2005).

Data collection comprised the identification and selection of circular business model development methods from academic literature and selected specialist sources in circular economy. For the scientific literature sources, the search was performed in Scopus and Web of Science databases in July 2017. The search string (("circular economy" OR "circle economy" OR circularity OR circle OR circular OR "closed loops") AND "business models" AND (method OR tool OR framework OR approach OR methodology OR procedure OR technique OR canvas)) was applied to topic (title-keywords-abstracts) and limited for articles in English. This resulted in one hundred and twenty-five articles. After removing duplicates, the authors applied some excluding criteria by screening title and abstracts, and selected twenty publications for full content reading. The selection procedure only considered articles that present methods for business model development (i.e., methods focusing solely on circular product 
design were disregarded), provide a detailed level of information, and do not focus on specific industry sectors (e.g., building and construction).

Due to the recent establishment of circular economy as a research area, other two literature review techniques were applied to complement the primary literature search. First, a snowballing approach was applied to the initial selected scientific articles to capture established and conceptual trends through cross-references. Six publications were added through this source. Then, other twenty influential nonpeer-reviewed publications from non-profits organizations or knowledge platforms on circular economy (such as the Ellen MacArthur Foundation; the Circular Economy Practitioner Guide published by the World Business Council for Sustainable Development; and the Knowledge Hub developed by Circle Economy) were also included. These techniques have been previously carried by authors from circular economy literature (Moreno et al., 2016; Aminoff et al., 2017; Blomsma and Brennan, 2017; Geissdoerfer et al., 2017) and are in accordance to literature review methodologies for management and organizational fields (Tranfield et al., 2003; Adams et al., 2017).

After reading the full content of the initial selected publications, the authors applied a new filter and selected the final ten publications for data analysis and reporting. This final list only considered publications presenting methods with characteristics of process models (a collection of organized and sequential activities that may be aggregated in stages and supported by tools to perform a specific objective, which in this case is the development of circular business models). Furthermore, the methods cover several stages of the business model development process (e.g., initiation, conceptualization, implementation).

Data analysis of the selected studies envisioned the definition of the key information to be collected and the procedure for analysis. In this study, the circular business model development methods described in the selected publications were investigated by applying techniques based on content analysis (Dresch et al., 2015) and categorized in regard to the extent that they support the integration with circular product design process (see the considered criteria in Table 1). The main author carried the categorization and a senior researcher validated the results. The criteria were developed to compare the different methods and also to explore if and how the methodological support has been evolving along the years, which is natural for fields - such as circular economy - that are still going through a maturing process.

Table 1. Level of integration of circular business model development methods with circular product design

\begin{tabular}{|c|c|}
\hline $\begin{array}{l}\text { Level of } \\
\text { integration }\end{array}$ & Business model development methods in this category: \\
\hline 1 & $\begin{array}{l}\text { - Do not mention product design, or/and; } \\
\text { - Refer to product design as a relevant step for circular economy but do not establish } \\
\text { a clear link with the business model development process, or/and; } \\
\text { - Have a reductionist interpretation of circular economy focusing on specific strategies } \\
\text { (e.g., servitization or Product/Service-Systems (PSS)). }\end{array}$ \\
\hline 2 & $\begin{array}{l}\text { - Indicate a collection of circular patterns/strategies to be applied in different stages of } \\
\text { the life cycle; } \\
\text { - Consider product design as one of the strategies/patterns for the beginning of life; } \\
\text { - Lack systematic approach or indication of potential relationships (how and what } \\
\text { types of product design strategies work as enablers or enhance benefits of the } \\
\text { designed circular business models) in between the circular design strategies/patterns } \\
\text { and the commercial or operational strategies/patterns to enhance the business } \\
\text { models' circularity. }\end{array}$ \\
\hline 3 & $\begin{array}{l}\text { - Systemically address circular business model development and product design } \\
\text { processes by establishing a connection in between them and with a clear indication } \\
\text { of their relationship (e.g., enabler or enhancer of benefits). }\end{array}$ \\
\hline
\end{tabular}

Data reporting included an overview of each circular business model development approach, followed by a description of the extent and how they integrate with circular product design, and finally the identification of potential research gaps. The results are summarized in Table 2 and presented in Section 3. 


\section{Circular business model development methods and their approach to circular product design}

The literature review identified ten circular business model development methods, as listed in Table 2 .

Table 2. Circular business model development methods and the level of integration with circular product design

\begin{tabular}{llll}
\hline Method & Authors (year of publication) & $\begin{array}{l}\text { Development } \\
\text { level }\end{array}$ & $\begin{array}{l}\text { Level of } \\
\text { integration }\end{array}$ \\
\hline $\begin{array}{l}\text { Guided choices towards a circular } \\
\text { business model }\end{array}$ & $\begin{array}{l}\text { Joustra et al. (2013) and } \\
\text { de Jong et al. (2015) }\end{array}$ & Experimental & 1 \\
\hline $\begin{array}{l}\text { Process for developing a business model } \\
\text { for a circular value chain }\end{array}$ & Roos (2014) & Theoretical & 1 \\
\hline $\begin{array}{l}\text { Circular Business Model Innovation } \\
\text { framework and the Business Cycle } \\
\text { Canvas }\end{array}$ & Mentink (2014) & Theoretical & 2 \\
\hline Circular Business Model Scan & Van Renswoude et al. (2015) & Experimental & 2 \\
\hline $\begin{array}{l}\text { Steps to starting the circular journey } \\
\text { The circular design guide }\end{array}$ & $\begin{array}{l}\text { The National Zero Waste Council } \\
\text { (2016) }\end{array}$ & Theoretical & 1 \\
\hline $\begin{array}{l}4 \text { steps towards a circular business } \\
\text { strategy with the Value Hill }\end{array}$ & EMF and IDEO (2016) & Experimental & 1 \\
\hline 10 steps towards a circular business & Kraaijenhagen et al. (2016) & Experimental & 2 \\
\hline BECE framework & Mendoza et al. (2017) & Theoretical & 3 \\
\hline
\end{tabular}

They were developed in the last four years and are in a large majority either theoretical (i.e., academic conceptual studies or case studies not yet validated in real industrial context) or experimental (i.e., based on industrial case studies or already being applied as industrial pilot projects for validation purposes or roll out). The level of integration or support to circular product design provided by these methods increased in the last two years. This temporal evolution is coherent and expected in a still maturing research field, such as circular economy. In a midterm horizon, the natural next steps for this research field are improvement (i.e., evolution to more structured and systematic methods), practical validation and consolidation of methodological support.

The majority of the selected methods at least moderately support product design, presenting level of integration 2 (i.e., they indicate a collection of circular patterns/strategies to be applied in different stages of the life cycle and consider product design as one of these strategies; however, they may lack systematic approach not establishing a relationship or addressing the potential synergistic combination of different strategies).

Achterberg et al. (2016) propose a four-step method to support organizations in understanding their current business and value chain and identifying opportunities to enable their transition to circular business models. The core of the method is the tool called Value Hill, which illustrates the relationship between the life cycle stages of a product and its added value by using the analogy of a hill. In the beginning of life, value is added to the product as they are designed (in analogy to going Up-Hill). In the middle of life, the value added to the product reach its peak (Tophill) as it is produced, commercialized and used by the stakeholders. In the end of life, there is a trend of degradation of value (DownHill) when the product is no longer in use and is discarded by the stakeholders. The objective of the Value Hill tool is helping the companies to configure their business model in a way that they always maintain the product value as high as possible with strategies in all life cycle stages covering circular design, optimal use, value recovery and network organization. To support the identification of opportunities, this approach provides a collection of twenty-one business model types (interpreted in this article as patterns/strategies for enhancing circularity) that could be applied along the different 
stages of the life cycle to enhance circularity of a business. Circular product design for long term value retention (making products that are easy to maintain, repair, upgrade, refurbish or remanufacture) is considered as a strategy for improving circularity in the beginning of life (Up-Hill). However, the approach does not envision a guideline on how to relate the adoption of strategies for optimizing value in the use phase (e.g., product leasing, renting, sharing platforms) or recovering value in the post-use phase (e.g., recycling, remanufacturing) with product design strategies. For instance, some of the strategies to optimize use will have enlarged benefits or only become viable with changes in product design.

Similar to the Value Hill, the Circular Business Model Scan (van Renswoude et al., 2015) adopts a business process improvement approach looking for gaps and opportunities to improve circularity along the offer's life cycle. Six business model archetypes with nineteen possible patterns/strategies applied at different points of the value chain (value proposition, design, supply, manufacturing, use, next life) are also presented with the objective of enhancing resource productivity. One of those strategies (called Cradle-to-Cradle) aims at promoting a pure cycle business model by integrating product redesign to enable closing materials loops. Although this is pointed as a strategy, similarly as in the Value Hill, there is no connection of how the other business model's strategies (e.g., dematerialized services, short or long use cycles, or cascading) will require or benefit from having certain circular product design practices in place. Again, a synergistic view of how to combine product design and business strategies (commercial model or operational model) is still missing.

Mentink (2014) presents a process framework for circular business model innovation called Circular Business Model Innovation (CBMI) framework. It contains five phases (Preparation, Initiation, Ideation, Integration and Implementation) in which eighteen key challenges encountered by companies when they move to circular economy are addressed. The $C B M I$ has a strong focus on the collaboration aspect and the systemic view of the value created and captured from the perspective of all actors of the value chain. To enable that non-firm centric view, Mentink (2014) introduces a tool called Business Cycle Canvas, which aims to describe the systemic business model composed by the sum of the business models of actors from the circular network. Similar to the previous approaches, the CBMI and the Business Cycle Canvas start with the analysis of the current life cycle to identify ways to close the loop of resources and energy. To support the ideation for circular business model opportunities, the process also envisions a collection of nineteen patterns that comprise changes in the way of providing the offer (e.g., dematerialized services and access over ownership) or designing the product (e.g., design for long-life; design hybrid product - durable product with short-lived consumables; design for attachment and trust; design for standardization and compatibility; design for maintenance and repair; design for upgradability and adaptability; design for disassemble and reassemble). Also, similar to the previous approaches, the $C B M I$ recognizes the product design as a pattern/strategy in circular business model innovation, nevertheless, it does not clearly indicate how to combine the changes in the commercial or operational aspects of the business model with product design strategies to optimize or simply enable the expected business results.

Two of the processes stood out and showed a higher level of support with a more systemic and systematic approach towards the integration of product design and business modelling.

Kraaijenhagen et al. (2016) propose a Ten-step process towards circular business with several tools suggested for each step. The approach is directed to the creation of circular businesses within existing organizations. It relies on soft skills and change management perspective to promote the collaboration and change in behaviours, thinking and actions. This process model presents one of the more robust indication of how to combine product design strategies - comprised in what they call technical aspects - with business model aspects and also with collaboration aspects (how to involve partners and customers) of the business. The authors present a framework of patterns/strategies for each of the aforementioned three aspects. They include case studies to exemplify how the patterns/strategies are being combined by businesses. Nevertheless, it does not indicate a generic pattern of combinations that could indicate the nature of their relationship (enabling or enhancing benefits). Another future improvement for this approach, could be providing guidelines or methodological support on how to apply the patterns/strategies' framework combined with or integrating them with the Conceptual Sustainable Business Model Framework, which is an adaptation (by dividing the value proposition 
element into economic, environmental, or societal value sources) of the Business Model Canvas (Osterwalder and Pigneur, 2010) proposed by them.

Finally, Mendoza et al. (2017) combine eco-design and backcasting in a ten-step process called $B E C E$ framework to support new business model development integrated with product design in a circular economy. The business model generated by the third step of the process is iteratively improved in the subsequent steps with feedbacks from the evaluation of the better product design strategies. Also, after the product design evaluation, BECE envisions applying the iReSOLVE framework (based on the Ellen McCarthur Foundation's ReSOLVE framework) to identify solutions to enhance circularity in between the pool of twenty-three available actions and requirements (interpreted in this article as patterns/strategies). These patterns/strategies range from product design-related to technology information infrastructure or systemic changes. As in Kraaijenhagen et al. (2016), the BECE framework does not indicate the relationship (enabling or enhancing benefits) neither possible combinations of different patterns/strategies. Instead, it suggests that the alternative patterns/strategies should be prioritized according to their implementation feasibility and serve as an evolutionary pool of mix-andmatch options for the company to apply along the time.

Although in general all methods recognize the importance of product design to the circular transition, some of them focus less on the integration aspects and support to product design. Examples are approaches that treat product design as a separate topic apart from business model innovation (National Zero Waste Council, 2016), lack a holistic view and address circular business modelling with a focus on single circular economy patterns/strategies (e.g., servitization) (Joustra et al., 2013; de Jong et al., 2015), or indicate the necessity of integrating product design but offer a very abstract level of support to mapping the design patterns/strategies (Roos, 2014). Also, there are cases of approaches that put more emphasis on supporting the product design aspects with superficial approach on how to connect that with the business model changes. For instance, the Circular Design Guide (Ellen MacArthur Foundation and IDEO, 2016) is one example of that. Based on a Design Thinking methodology, the Circular Design Guide envisions a four-stage process (understand, define, make and release) to foster circularity. The guide works as well as a toolkit, with the indication of sixteen tools to be applied along the four stages. In terms of tools to support business modelling, the guide applies a traditional approach by proposing the use of an adapted version (by adding questions associated to the circularity context) of the Business Model Canvas (Osterwalder and Pigneur, 2010). The innovativeness and strength of this approach is the suggestion of other tools that precede the business model integration and aim to define the value opportunities or propositions (such as the tools Define your Challenge; Circular Buy In; Find Circular Opportunities; Service Flip; Understand Circular flows; Regenerative Thinking). However, the toolkit is more similar to a framework at a high level of abstraction to enable the flexibility for companies to instantiate it according to each situation. Consequently, it is less systematic and do not clearly identify what tools should be combined or applied in sequence. Due to the nature of the Circular Design Guide, the final result regarding the level of integration of product design and circular business modelling process rely on the expertise (either on circular economy, design thinking, product or business model innovation) of the practitioners or users applying it.

\section{Discussion: Conceptual approaches to relate circular business model and circular product design}

As identified by the results, there is still room for improving the extent to which business models' development methods address and support product design. The two methods with the highest level of support (Kraaijenhagen et al., 2016; Mendoza et al., 2017) apply different approaches to promote the integration. Mendoza et al. (2017) combine methods for business model development (backasting) and product design (eco-design) to promote the integration. Kraaijenhagen et al. (2016) propose a framework that introduces equivalent circular patterns/strategies for business models and product design, and that can be used as an add-on with already existing (e.g., business model canvas) or adapted business model tools for circular economy to inspire the ideation.

From observing this difference, one question for future discussion arises: is it necessary to integrate the process models (methods) from product design and business model development or could frameworks 
or typologies of circular strategies linking business model and product design be used as add-on to the business model development process model (method)?

\subsection{Trends in current works}

Analyzing some recent conceptual publications on circular economy, there seems to exist a trend for the adoption of the latter option. Previous studies have already been working on improving the frameworks that match circular product design strategies/patterns with the definitions taken for circular business model.

For instance, Bocken et al. (2016) identify three key strategies for circular economy: narrowing loops, slowing loops or closing loops. Narrowing loops involves resource efficiency and using few resources per product. Slowing loops involves optimizing and extending the use of products to slow down the flow of resources. Closing loops includes promoting circular flows of resources by recycling. For enabling the closing or slowing the loops strategies, they identify complementary practices in terms of circular product design and circular business models' development as outlined in Table 3.

Table 3. Connection of circular business model development and circular product design strategies/patterns as proposed by Bocken et al. (2016)

\begin{tabular}{|c|c|c|}
\hline Key strategies & Circular business model strategies & Circular product design strategies \\
\hline Slowing & $\begin{array}{l}\text { - Access and performance model } \\
\text { - Extending product value } \\
\text { - Classic long-life } \\
\text { - Encourage sufficiency }\end{array}$ & $\begin{array}{l}\text { - Design for long-life products } \\
\circ \text { Design for attachment and trust } \\
\circ \text { Design for reliability and durability } \\
\text { - Design for product life-extension } \\
\circ \text { Design for ease of maintenance and repair } \\
\circ \text { Design for upgradability and adaptability } \\
\circ \text { Design for standardization and compatibility } \\
\circ \text { Design for dis - and reassembly }\end{array}$ \\
\hline Closing & $\begin{array}{l}\text { - Extending resource value } \\
\text { - Industrial symbiosis }\end{array}$ & $\begin{array}{l}\text { - Design for a technological cycle } \\
\text { - Design for a biological cycle } \\
\text { - } \quad \text { Design for dis- and reassembly }\end{array}$ \\
\hline
\end{tabular}

Moreno et al. (2016) build upon Bocken et al. (2016) and clearly establish the potential connection between circular business model strategies and product design strategies, also positioning them within the stages that they usually occur along the value chain as listed in Table 4.

\subsection{Potential improvements to be explored as evolutionary actions}

An evolutionary step to complement Bocken et al. (2016) and Moreno et al. (2016) and use these conceptual frameworks as add-ons for circular business model development methods would be clarifying if there are generic trends in the synergistic relationship (e.g., enabling or benefit enhancing effects) between circular business models and product design strategies. The questions to be explored to discover that are for example:

- Are there circular business model strategies that require specific product design strategies to become viable?

- Are there product design strategies that could enhance the possible benefits (economic, environmental or social) obtained through the selected business model strategy?

- Is it possible to establish these generic synergistic patterns at a sector level or only at each company's level (i.e., when the solutions are being instantiated in each specific organizational context)?

Another improvement for these conceptual frameworks, could be the explicit inclusion of strategies directly related to resource efficiency and cleaner production (called narrowing loops by Bocken et al. (2016)), which would affect the production processes of the organizations. This is already envisioned in the Circular Economy Framework proposed by Weetman (2016). For instance, the 
frameworks could be expanded even more to relate business model strategies with all business processes from the organization and also external organizational aspects (e.g., legislation and infrastructure schemes) to propose a methodological support that will guide industries in a more systemic and systematic way.

Table 4. Connection of circular business model development and circular product design strategies/patterns as proposed by Moreno et al. (2016)

\begin{tabular}{|c|c|c|c|}
\hline $\begin{array}{l}\text { Position in value } \\
\text { chain }\end{array}$ & Key strategies & $\begin{array}{l}\text { Circular business model } \\
\text { strategies }\end{array}$ & Circular product design strategies \\
\hline $\begin{array}{l}\text { Manufacturing, } \\
\text { distribution/sales, } \\
\text { use and } \\
\text { maintaining }\end{array}$ & $\begin{array}{l}\text { Slowing } \\
\text { resource loops }\end{array}$ & $\begin{array}{l}\text { - Extending product value } \\
\text { - Sharing platforms }\end{array}$ & $\begin{array}{l}\text { - Design for systems change } \\
\text { - Design for long-life use of } \\
\text { products } \\
\text { - } \\
\text { - Design for multiple cycles } \\
\text { Design for resource conservation }\end{array}$ \\
\hline $\begin{array}{l}\text { Manufacturing, } \\
\text { distribution/sales, } \\
\text { use, maintaining } \\
\text { and end of life }\end{array}$ & $\begin{array}{l}\text { Cycling for } \\
\text { longer }\end{array}$ & - Product life extension & \multirow{2}{*}{$\begin{array}{l}\text { - Design for systems change } \\
\text { - Design for long-life use of } \\
\text { products } \\
\text { - Design for multiple cycles } \\
\text { - Design for resource conservation } \\
\text { Design for circular supplies }\end{array}$} \\
\hline $\begin{array}{l}\text { Resources, } \\
\text { manufacturing } \\
\text { and end of life }\end{array}$ & Cascade uses & - Resource value & \\
\hline $\begin{array}{l}\text { Resources and } \\
\text { end of life }\end{array}$ & $\begin{array}{l}\text { Narrowing } \\
\text { resource flows }\end{array}$ & - Circular supplies & $\begin{array}{l}\text { - Design for systems change } \\
\text { - Design for resource conservation } \\
\text { - Design for circular supplies }\end{array}$ \\
\hline
\end{tabular}

Finally, it is important to explore as well how to effectively apply these add-on frameworks within the business model development process. Sometimes, the full implementation of the "ideal" circular business models will not be able in a short-term horizon due to the necessity of having the new circular products developed (Laubscher and Marinelli, 2014). Understanding this readiness perspective of the products may help the organizations to plan their transition to more circular business in a gradual way. For instance, they could develop and implement several circular business models until they achieve the initial desired model with new products fit for circular purpose. The add-on frameworks - if improved with the identification and connection of relationships in between the strategies (e.g., selling services instead of products will only be possible if the products are redesigned for remanufacturing, and it could have higher profits if the products were redesigned for ease of maintenance) - could support companies in identifying, prioritizing and planning their actions for their circular transition.

\section{Concluding remarks}

Based on a comprehensive literature review, this paper has explored the synergistic relationships between business model development methods and circular product design process. The literature review provided an understanding of the current methodological support to develop circular business models and enabled the elucidation of gaps and opportunities for improvement regarding how these methods support the integration with circular product design.

The main conclusions and insights are summarized as follows:

- There are still gaps in the extent to which circular business model's development methods address the integration with circular product design;

- Most of the circular business model's development methods recognize the importance of product design strategies and suggest their use without relating or indicating potential combinations with other synergistic strategies that could be applied for value optimization in the use phase or recover of value in the end of life; 
- Two conceptual frameworks (Bocken et al., 2016; Mendoza et al., 2017) try to address this gap by relating product design and business model development strategies for circular systems;

- There is an opportunity for better understanding the types of relationship and patterns (e.g., conditional, beneficial, trade-off, and so on) between business model development and circular product design;

- Similarly to the connections of circular business model's development with product design, the integration with other business processes of the organization - such as collaboration and value chain, production processes improvement for resource efficiency (i.e., narrowing the loop strategies (Bocken et al., 2016)), information and communication technology - and other external aspects - such as legislation, and infrastructure - could also be explored to assure a systemic view and enrich the methodological support to be provided to companies.

- Several methods have a reductionist approach towards business model (compared to the definition presented in the Introduction section) interpreting it solely as the commercial or the revenue model;

- In general, there is no integration of how the circular strategies/patterns relate to the different elements or dimensions of a business model (value creation, delivery and capture) and this investigation could be another opportunity for future works.

This study complements current circular economy research by expanding the understanding of theoretical foundations to guide the development of appropriate methodological support for organizations that are planning to engage in circular economy. The main contributions of this work are the consolidation of the circular business model development methods and the identification of opportunities for improvement in the extent that they address the integration with product design.

The main limitations of this study are related to the techniques employed in the literature review. The snowballing and inclusion of non-peer reviewed materials from specialist institutions may generate selection bias. Also, the indication of the opportunity for better understanding the types of relationship and patterns (e.g., conditional, beneficial, trade-off) in between business model and circular product design is a hypothesis that need to be validated in practice.

This article was defined in a way to enhance the understanding of how the circular business model development methods for circular economy are addressing the challenge of integration with product design. Future research should focus on a complementary view, of identifying how other business processes of the organizations (such as technology innovation, procurement and supply chain, information and communication technology (ICT) systems, and so on), and also external aspects (such as infrastructure and legislation) should be addressed by business modelling approaches (Bocken et al., 2016; Moreno et al., 2016). This exploratory study and its insights will serve as one of the foundations for the development of a dynamic tool for sustainable circular business model conceptualization. This tool will be co-developed and broadly validated by companies from varied branches. Future work also includes the consolidation of a process model for sustainable circular business model innovation.

\section{Acknowledgments}

This work is an outcome of the research project CIRCit (Circular Economy Integration in the Nordic Industry for Enhanced Sustainability and Competitiveness), which is part of the Nordic Green Growth Research and Innovation Programme (grant number: 83144) and funded by NordForsk, Nordic Energy Research, and Nordic Innovation. We would like to thank the CIRCit consortium for their collaboration and enriching discussions about circular economy and sustainability.

\section{References}

Achterberg, E., Hinfelaar, J. and Bocken, N. (2016), Master Circular Business With the Value Hill. [online] Circle Economy. Available at: https:/www.circle-economy.com/wp-content/uploads/2016/09/finance-white-paper20160923.pdf (accessed 15.07.2017). 
Adams, R.J., Smart, P. and Huff, A.S. (2017), "Shades of Grey: Guidelines for Working with the Grey Literature in Systematic Reviews for Management and Organizational Studies", International Journal of Management Reviews, Vol. 19 No. 4, pp. 432-454. https://doi.org/10.1111/ijmr.12102

Aminoff, A., Valkokari, K., Antikainen, M. and Kettunen, O. (2017), "Exploring Disruptive Business Model Innovation for the Circular Economy", Proceedings of the International Conference on Sustainable Design and Manufacturing (SDM 2017), Bologna, Italy, April 26-28, 2017, Springer, Cham, pp. 525-536. https://doi.org/10.1007/978-3-319-57078-5_50

Balkenende, A.R. and Bakker, C.A. (2015), "Developments and Challenges in Design for Sustainability", In: Curran, R., Wognum, N., Borsato, M., Stjepandic, J. and Verhagen, W.J.C. (Eds.), Transdisciplinary Lifecycle Analysis of Systems, IOS Press BV, Amsterdam. https://doi.org/10.3233/978-1-61499-544-9-3

Biolchini, J., Mian, P.G., Natali, A.C.C. and Travassos, G.H. (2005), Systematic Review in Software Engineering. [online] PESC - System Engineering and Computer Science Department COPPE/UFRJ, Rio de Janeiro, Brazil. Available at: http://www.cos.ufrj.br/uploadfile/es67905.pdf (accessed 01.12.2017).

Blomsma, F. and Brennan, G. (2017), "The Emergence of Circular Economy: A New Framing Around Prolonging Resource Productivity”, Journal of Industrial Ecology, Vol. 21 No. 3, pp. 603-614. https://doi.org/10.1111/jiec.12603

Bocken, N.M.P., de Pauw, I., Bakker, C. and van der Grinten, B. (2016), "Product design and business model strategies for a circular economy”, Journal of Industrial and Production Engineering, Vol. 33 No. 5, pp. 308320. https://doi.org/10.1080/21681015.2016.1172124

Colby, C.C. (2011), The Relationship Between Product Design and Business Models in the Context of Sustainability, Master thesis, University of Montreal.

de Jong, E., Engelaer, F. and Morice, M. (2015), Realizing opportunities of a circular business model. [online] De Lage Landen (DLL) - final solutions partner, The Netherlands. Available at: http://images.info.yoursolutionspartner.com/Web/servicedllgroupcom/\%7Bee927947-b65e-4360-a15379b0f9ed68d7\%7D_Whitepaper_-

_Realizing_opportunities_of_a_circular_business_model.pdf?elqaid=71\&elqat $=2$ \&elqTrackId=2f5d60d79e7 44ee599ecea50b13497e9 (accessed 01.07.2017).

Den Hollander, M. and Bakker, C. (2016), "Mind the Gap Exploiter: Circular Business Models for Product Lifetime Extension", Proceedings of the International Congress Electronic Goes Green 2016+ (EGG 2016): Inventing shades of green, Berlin, Germany, September 7-9, 2016, Fraunhofer IZM Berlin, Berlin, Germany, pp. 1-8.

Dresch, A., Lacerda, D.P. and Antunes Jr., J.A.V. (2015), Design Science Research-A Method for Science and Technology Advancement, Springer International Publishing, Cham, Switzerland. https://doi.org/10.1007/9783-319-07374-3

Ellen MacArthur Foundation (2012), Towards the Circular Economy Vol. 1: An Economic and Business Rationale for an Accelerated Transition. [online] Ellen MacArthur Foundation Publishing. Available at: https://www.ellenmacarthurfoundation.org/assets/downloads/publications/Ellen-MacArthur-FoundationTowards-the-Circular-Economy-vol.1.pdf (accessed 01.12.2017).

Ellen MacArthur Foundation (2015), Growth within: a circular economy vision for a competitive Europe. [online] Ellen MacArthur Foundation Publishing. Available at: https://www.ellenmacarthurfoundation.org/assets/downloads/publications/EllenMacArthurFoundation_Grow th-Within_July15.pdf(accessed 01.12.2017).

Ellen MacArthur Foundation and IDEO (2016), The Circular Design Guide. [online] Ellen McArthur Foundation Publishing. Available at: https://www.circulardesignguide.com (accessed 01.12.2017).

European Comission (2014), Towards a circular economy: A zero waste programme for Europe. [online] Available at: http://eur-lex.europa.eu/legal-content/EN/TXT/?uri=CELEX:52014DC0398R\%2801\%29 (accessed 02.10.2017).

Geissdoerfer, M., Savaget, P., Bocken, N.M.P. and Hultink, E.J. (2017), "The Circular Economy - A new sustainability paradigm?", Journal of Cleaner Production, Vol. 143, pp. 757-768. https://doi.org/10.1016/j.jclepro.2016.12.048 
Ghisellini, P., Cialani, C. and Ulgiati, S. (2016), "A review on circular economy: the expected transition to a balanced interplay of environmental and economic systems", Journal of Cleaner Production, Vol. 114, pp. 11-32. https://doi.org/10.1016/j.jclepro.2015.09.007

Häyhä, T., Lucas, P.L., van Vuuren, D.P., Cornell, S.E. and Hoff, H. (2016), "From Planetary Boundaries to national fair shares of the global safe operating space - How can the scales be bridged?", Global Environmental Change, Vol. 40, pp. 60-72. https://doi.org/10.1016/j.gloenvcha.2016.06.008

Joustra, D.J., de Jong, E. and Engelaer, F. (2013), Guided Choices: towards a Circular Business Model. [online] Project C2C Bizz, Eindhoven, The Netherlands. Available at: http:/www.c2cbizz.com/tools/guided-choicestowards-a-circular-business-model-en.pdf

Kiørboe, N., Sramkova, H. and Krarup, M. (2015), Moving towards a Circular Economy - successful Nordic business models: Policy brief. [online] Nordic Council of Ministers, Copenhagen, Denmark. Available at: http://norden.diva-portal.org/smash/get/diva2:852029/FULLTEXT01.pdf (accessed 01.07.2017).

Kraaijenhagen, C., van Open, C. and Bocken, N. (2016), Circular Business - Collaborate and Circulate, Circular Collaboration, Amersfoort, The Netherlands.

Laubscher, M. and Marinelli, T. (2014), "Integration of Circular Economy in Business", Proceedings of the 10th Going Green - CARE INNOVATION Conference: Towards a Resource Efficient Economy, Vienna, Austria, November 17-20, 2014. https://doi.org/10.13140/2.1.4864.4164

Lieder, M. and Rashid, A. (2016), "Towards circular economy implementation: a comprehensive review in context of manufacturing industry”, Journal of Cleaner Production, Vol. 115, pp. 36-51. https://doi.org/10.1016/j.jclepro.2015.12.042

Mendoza, J.M.F., Sharmina, M., Gallego-Schmid, A., Heyes, G. and Azapagic, A. (2017), "Integrating Backcasting and Eco-Design for the Circular Economy: The BECE Framework", Journal of Industrial Ecology, Vol. 21 No. 3, pp. 526-544. https://doi.org/10.1111/jiec.12590

Mentink, B. (2014), Circular Business Model Innovation A Process Framework and a Tool for Business Model Innovation in a Circular Economy, Master thesis, Delft University of Technology and Leiden University.

Mikkola, N., Randall, L. and Hegberg, A. (2016), Green Growth in Nordic Regions: 50 ways to make it happen. [online] Nordregio, Stockholm. Available at: http://norden.divaportal.org/smash/record.jsf?pid=diva2\%3A957463\&dswid=2782 (accessed 01.06.2017).

Moreno, M., De los Rios, C., Rowe, Z. and Charnley, F. (2016), “A Conceptual Framework for Circular Design”, Sustainability, Vol. 8 No. 9, pp. 937. https://doi.org/10.3390/su8090937

National Zero Waste Council (2016), National Zero Waste Council Circular Economy Business Toolkit. [online] National Zero Waste Council (NZWC), Canada. Available at: http://www.nzwc.ca/Documents/CircularEconomyBusinessToolkit.pdf (accessed 20.07.2017).

Osterwalder, A. and Pigneur, Y. (2010), Business Model Generation: A Handbook for Visionaries, Game Changers and Challengers, Wiley \& Sons, Hoboken, New Jersey.

Pigosso, D. and McAloone, T. (2017), "How can design science contribute to a circular economy?", Proceedings of the 21st International Conference on Engineering Design (ICED '17), Vol. 5: Design for X, Vancouver, Canada, August 21-25, 2017, The Design Society, Glasgow, pp. 299-307.

Rolls-Royce (2018), TotalCare ${ }^{\circledR}$. [online] Rolls-Royce. Available at: https:/www.rolls-royce.com/media/ourstories/discover/2017/totalcare.aspx (accessed 03.05.2018).

Roos, G. (2014), "Business Model Innovation to Create and Capture Resource Value in Future Circular Material Chains", Resources, Vol. 3 No. 1, pp. 248-274. https://doi.org/10.3390/resources3010248

Steffen, W. and Stafford Smith, M.D. (2013), "Planetary boundaries, equity and global sustainability: why wealthy countries could benefit from more equity”, Current Opinion in Environmental Sustainability, Vol. 5 No. 3-4, pp. 403-408. https://doi.org/10.1016/j.cosust.2013.04.007

Tranfield, D., Denyer, D. and Smart, P. (2003), “Towards a Methodology for Developing Evidence-Informed Management Knowledge by Means of Systematic Review”, British Journal of Management, Vol. 14 No. 3 , pp. 207-222. https://doi.org/10.1111/1467-8551.00375

van Renswoude, K., ten Wolde, A. and Joustra, D.J. (2015), Circular Business Models - Part 1: An Introduction to IMSA's Circular Business Model Scan. [online] IMSA, Amsterdam. Available at: https://groenomstilling.erhvervsstyrelsen.dk/sites/default/files/media/imsa_circular_business_models__april_2015___part_1.pdf(accessed 20.07.2017). 
Vigga (2017), What if clothes could grow with your child? [online] VIGGA.us. Available at: https:/vigga.us/inenglish/ (accessed 03.05.2018).

Weetman, C. (2016), A Circular Economy Handbook for Business and Supply Chains: Repair, Remake, Redesign, Rethink, Kogan Page Publishers, New York.

Marina de Padua Pieroni, Doctoral Researcher

Technical University of Denmark, Mechanical Engineering

Akademivej, 2800 Lyngby, Denmark

Email: mdpp@dtu.dk 